\title{
AN OVERVIEW IN URBAN GEOLOGY AND URBAN GEOMORPHOLOGY
}

\author{
Bathrellos G. D. ${ }^{1}$ \\ ${ }^{1}$ National and Kapodistrian University of Athens, Faculty of Geology and Geoenvironment, \\ Department of Geography - Climatology,gbathrellos@geol.uoa.gr
}

\begin{abstract}
Worldwide is observed an expansion in urban areas. In Greece a proportional phenomenon is mentioned. More than 52\% of the Greek population now lives in the two metropolitan municipalities of Athens and Salonica.

For this reason grows up the scientific interest to urban geology and urban geomorphology. Urban Geology is the application of geologic knowledge to the planning and management of metropolitan areas. Its domain spans both regional geology and applied geology. Urban Geomorphology is the study of man as a physical process of change whereby he metamorphoses a more natural terrain to an anthropogene cityscape. In such a context Urban Geomorphology is the surface component of Urban Geology, which is one of the important subfields of environmental geology.

The urban geomorphology is related with the management of natural hazards and the spatial planning. Engineering geology and urban planning need to interface with geomorphology in hazardous areas.
\end{abstract}

Key words: urbanization, urban planning, geomorphologic hazards.

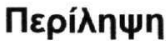

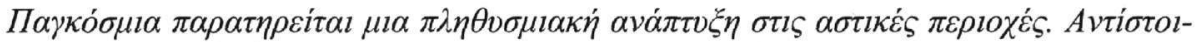

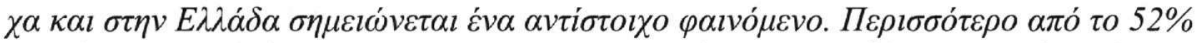

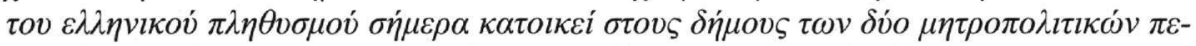

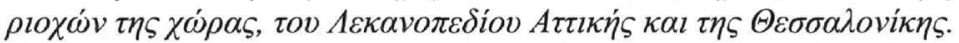

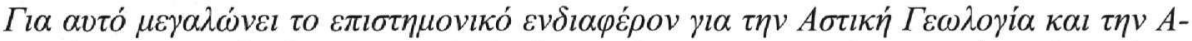

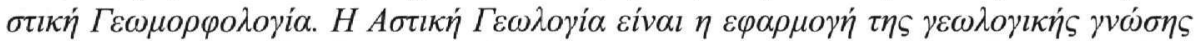

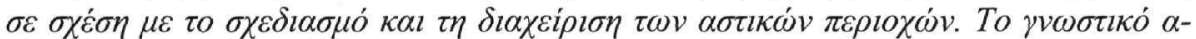

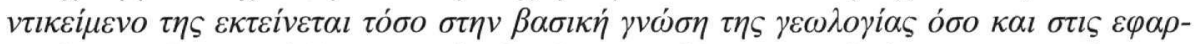

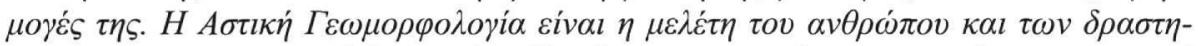

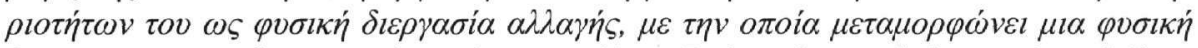

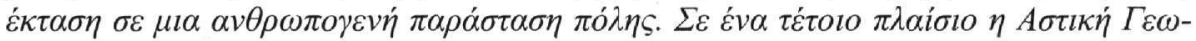

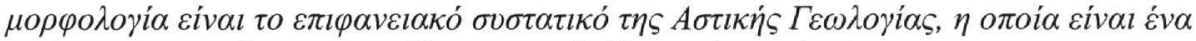

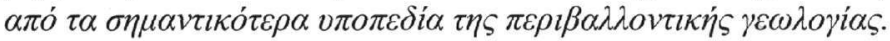

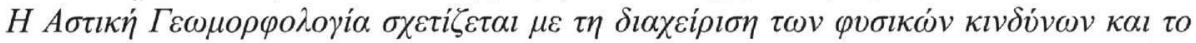

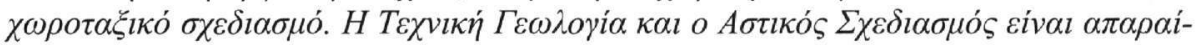

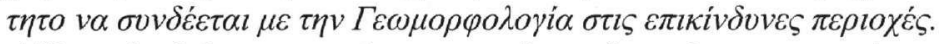

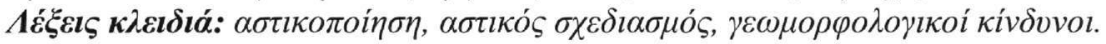




\section{Urban expansion}

The power of urbanization and a swiftly expanding chemical industry have been responsible for huge ameliorations in the quality of life over the last 160 years, on a global level. Paradoxically, these same forces now threaten the global environment. Urban areas are characterized by intense and often unregulated industrial activity, rapid and poorly planned growth, the fragmentation of natural habitats, and the degradation of surface and ground waters by a wide range of chemical contaminants (Eyles 1997).

More than $70 \%$ of the world's population now lives in urban areas and there are more than 20 so-called "supercities" each containing more than $10 \%$ of their respective national populations. Examples include Mexico City (31\% of national population), Buenos Aires (42\%), Cairo (36\%), and Sao Paulo (17\%; Turner et al. 1990, United Nations Population Fund 1991). Whereas the growth of cities is the engine of the world economy and generates enormous social benefits by concentrating human creativity, most global environmental problems of the late $20^{\text {th }}$ century can be linked directly to the massive transfers of resources and waste products required by large cities. Terms such as "urbanization" (Fig. 1), "economic imbalance", and "environmentally unsustainable" are becoming synonymous (Tabibzadeh et al. 1989, Stren et al. 1992, Socolow et al. 1994, Drakakis-Smith 1995). In

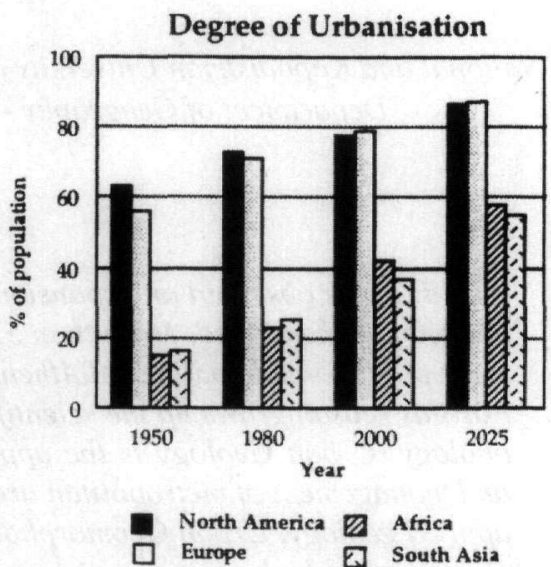

Figure - 1 Degree of urbanization (Mulder 1996) 1950 , there were 83 cities with populations greater than 1 million; today, there are more than 280 cities and this total will double by 2015. The ten largest supercities are listed in figure 2 (Eyles 1997).

In Greece, it is observed a proportional phenomenon. More than $52 \%$ of the Greek population now lives in the two metropolitan municipalities of Athens and Salonica. Also the grater percentage of the immigrants lives nowadays in the Greek cities and towns. More than $40 \%$ of the Greek population lives in the municipalities of Attica.

\section{Urban geology}

Urban geology is a specialty few geologists claim. Its domain spans both regional geology and applied geology. Some emphasis is usually assumed in the application of geological principles and knowledge to the solution of construction, and now environmental, problems in or near urban areas (Karrow and White 1998).

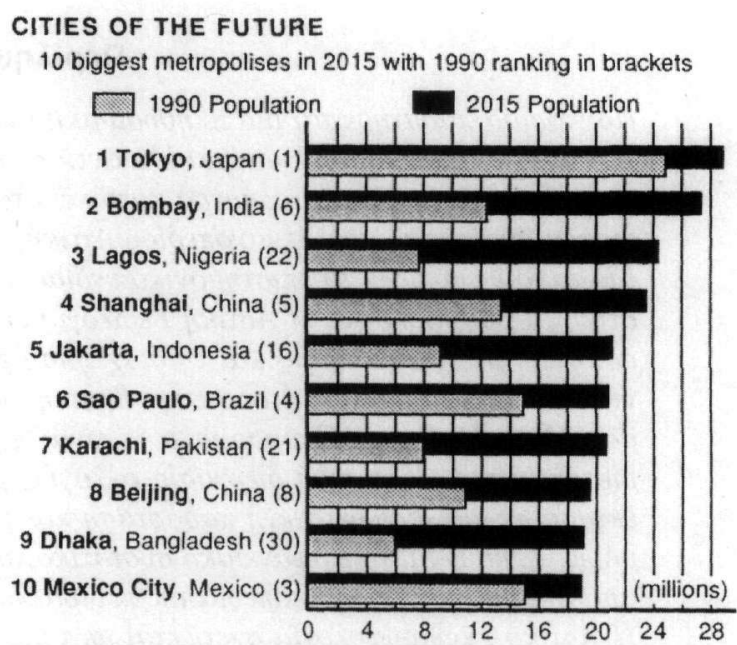

Figure 2 - Expected ten largest supercities as of 2015, with 1990 ranking in parentheses (Eyles 1997) 
Whereas geologists have worldwide a long history of working in cities alongside engineers (e.g. Legget 1973, Leveson 1980), the artificial, built landscapes of urban areas have, by and large, been seen as "poor places to do geology" (Walton 1982).

Urban geology is the application of geologic knowledge to the planning and management of metropolitan areas. Involved in this field of geology are the subdisciplines that contribute to water supply and waste disposal, site investigation for hazardous conditions, and delineation of economic rock and mineral deposits. Most aspects of engineering geology are applied in the urban setting, including the analysis and interpretation of rocks, soil, and groundwater for the purposes of planning and design of engineering structures. Both engineering and urban geology are part of the wider field of environmental geology, which includes the study of resource exploitation, waste disposal, geologic hazards, medical geology, and the environmental impact of humans. Many of these problems are of prime importance in the urban environment, and since the introduction of the term "environmental geology" in the middle 1960s, the terms urban geology, applied geology, and, to a lesser extent, engineering geology, have been less frequently employed. Almost any traditional field of geology can contribute to environmental geology; the determining factor is a commitment to provide information on the geologic environment to serve society's needs (Utgard et al. 1978). It is mentioned that a standard metropolitan statistical area (SMSA) is defined by the U.S. Bureau of Census as a county or group of contiguous counties which contains at least one city of 50,000. In addition to counties containing such cities, contiguous counties are included in, an SMSA if, according to certain criteria, they are socially and economically integrated with the central city.

Traditional approaches to "urban geology" have focused mostly on the engineering behavior of the various geological materials below cities in terms of their stability for roads, foundations, etc. Provision of adequate construction materials has also been a major concern. The principal environmental geological concerns in urban areas includes the provision of sufficient drinking water, waste disposal, soil and landscape degradation, and the increasing vulnerability of densely populated urban areas to geological hazards and environmental disasters. Environmental geologists working on such problems are, in the main, employed by the environmental-consulting sector (Eyles 1997).

In Canada and USA, the public concern with urban environmental and health issues heightened and is reflected in new planning legislation and land use regulations. In turn, environmental geological investigations centered on urban areas encompass a very broad range of issues. There is increasing interest by private companies and financial institutions (particularly insurance and banking) concerned with the safety of investments arising from litigation over contaminated properties or geological hazards, and the need for clients to recognize and comply with environmental regulations.

Another growing recognition of the importance of urban environmental and engineering geology in Canada and USA, and the need for an increased body of professionals, is reflected in new programs in universities and colleges and the availability of textbooks.

\section{Urban geomorphology}

Geomorphology is the science of landforms and the processes that create them. In the urban environment man is the creator of the landscape or "cityscape". Thus, urban geomorphology is the study of man as a physical process of change whereby he metamorphoses a more natural terrain to an anthropogene cityscape. In such a context urban geomorphology is the surface component of urban geology, which is one of the important subfields of environmental geology (Coates 1976).

Man lives, works, and plays on the surface of the Earth and nearly all his activities transform the surface in some manner. Maximum distortion occurs, however, in urban areas where he has chosen to congregate and congest. The emphasis of urban geomorphology is on this unique geographic 
setting where man has so thoroughly intruded that he has overwhelmed many of nature's physical systems. The study of these aberrations, some of which are deliberate while others are by-products, constitutes one of the subfields of geomorphology (Coates 1976). The urban geomorphologist can use his expertise to predict the kind of destruction that will ensue from man's construction enterprises when the type, degree, and magnitude of the environmental upsets are understood. It is not sufficient for the scientist to "merely know" what will happen, but he should become involved in decision-making matters. It is necessary to provide advice for those plans that seek alternate paths whereby man's activities can be consummated in a manner that will minimize environmental degradation (Coates 1976).

Urban geomorphology examines the changes caused by the requirements of urban residential, economic and traffic functions (Cooke 1976, Cooke et al. 1982). Towns are adjusted to the relief and the relief is also adjusted to the needs of construction and planning (Ahnert 1996). The changes that occur as a result of urban development are also influenced by their interaction with the disturbed geomorphological process response systems, such as weathering on building stone resulting from air pollution (Viles 1993).

Local landforms have played a central role throughout history in the choice of sites for settlements and their further development has often been influenced by the regional geomorphology. The location of Italian cities on defensive hill sites, the development of the Greek city states in fertile basins surrounded by hills, locations at easy river crossings, on terraces above flood levels, on bays, at the landward end of navigable estuaries or at the exit of large mountain valley systems on to a foreland are some examples. Villages located in spring hollows, along valley floors or on sandy upland bordering marsh areas all once took advantage of the local relief and hydrological conditions. Settlement geography is incomplete without taking into account the morphography and hydrology of the area (Ahnert 1996).

Erosion increases in urban areas when, for example, building activity bares the soil and causes extensive wash denudation. The streams become overloaded with sediment as a result and their cross-sections are changed (Wolman 1967, Wolman and Schick 1967). Road building has a similar effect, particularly the construction of multi-lane highways. As urban areas expand, more soil surfaces are sealed by buildings, streets, parking areas, industrial and commercial activity so that the surface runoff flows into the sewage system. Groundwater supplies are reduced as a result and flood frequency and the peak flood height are increased (Leopold 1968, Graf 1975, Sala and Inbar 1992). Gupta (1984) has discussed the special geomorphological and hydrological problems of cities in the tropics.

Human activity has increased the runoff maxima in many river basins, and this has been compensated for by the building of reservoirs which store the excess runoff and release it gradually. Reservoir basins are also sediment traps for all the bed load and at least part of the suspended load. Immediately below the dam the stream is practically free of solid load so that it picks up new load and erodes its channel bed downstream from the reservoir. The bed load is smaller than before because the high-water peaks are lower than before the dam was completed (Gregory and Park 1974, Gregory 1979).

Many articles have been written on various aspects of urban geomorphology. Three completed editions - books have been published on this subject by Detwyler and Marcus (1972), Coates (1974) and Legget (1973).

\section{A bibliographic review in urban geology}

The first urban geological activities traceable in literature date back as far as the end of $19^{\text {th }}$ and the beginning of $20^{\text {th }}$ century. The first urban geology studies they were worked out in Canada by H.M. Ami. 
Although the 1900 paper by Ami "On the Geology of the Principal Cities in Eastern Canada" is often cited as the pioneering work, this paper was the culmination of his earlier papers dealing individually with the cities of Ottawa, Montreal and Quebec (Ami, 1885, 1891, 1892 and 1897); overlapping with these were papers by Dresser (1897) and Adams (1898) on Montreal (Karrow and White, 1998).

In more recent times, the distinguished spokesman for urban geology was R.F. Legget. His book "Cities and Geology" (Legget 1973) remains the best known on the subject. This internationally known authority delivered many invited lectures on urban geology, richly illustrated with examples from around the world. His brief brochure, simply titled "Urban Geology" (Legget 1969), was distributed by the National Research Council Division of Building Research, of which he was its founding and long-time Director.

In Germany, special soil maps were made to support urban planning (Hoyningen-Huene 1931, Stremme 1932). Towards the end of the thirties the Preussischen Geologischen Landesanstalt in Germany (Bruning 1940) combined detailed maps on scales of 1:10,000 and 1:5,000 with maps indicating the suitability for various kinds of land-use and compiled these into a "Bodenatlas" for urban expansion. As a result of the population explosion and the economic revival immediately after World War II, the amount of urban geological activities increased substantially in many countries, especially in Europe and North America. New systematic geological mapping programs were set up in, for example, Germany, Czechoslovakia and the Netherlands. These were intended to support physical planning and pay attention to physical properties of rocks as well as the succession of strata in the subsurface (Hageman, 1963). An excellent example of such urban geological activities was the detailed (scale 1:5,000) mapping of foundation conditions in the city of Prague. The numerous data and maps of this city are constantly updated (Legget 1973). For more than a dozen German cities atlases with thematic land-use maps have been prepared (Munchenhausen and Muller 1951). Although these were obviously intended for urban planning, their readability is generally poor. To economize on the high (color) printing costs, too much information was crammed into too few maps. Information about soil properties and suitability for various kinds of land-use was presented on the maps and in the explanatory notes in qualitative terms only. This was undoubtedly due to the very limited availability of geotechnical and geohydrological in-situ and laboratory test results (de Mulder 1996).

As a result of the explosive economic growth in the United States of America after World War II and the subsequent urban expansion, the number of geologists concerned with urban geology increased rapidly. For example, at the end of the sixties, about 150 geologists were employed in this field in the city of Los Angeles alone (McGill 1973). In the same period a break-through in the use of geological data for urban planning and management was achieved in Canada mainly on account of the publications of Legget (Legget 1973, White 1989). In industrialized countries concern about our natural environment grew, and the dangers of pollution caused by large-scale waste-disposal, predominantly in and around urban centers, became apparent in the seventies. Detection, immobilization and restoration of polluted areas and selection of appropriate sites for waste disposal opened up a new field of interest and created a new challenge for urban geologists. Geochemistry was added to their expertise and environmental geology became the focus for a rapidly accumulating number of new studies. This resulted in new ways of informing planners about the potentials and the limitations of the soil. "Geopotential maps", on which preferential land-use based on Earth-scientific and related discipline is indicated, were first introduced in the Federal Republic of Germany (Luttig, 1978). This mapping system was later applied in several other countries, for example Togo, India and Indonesia. Many urban geological maps were made and printed by the US Geological Survey during this decade (e.g. McGill 1973, Baskerville 1981, Merguerian and Baskerville 1987).

In various European countries special studies were carried out, mainly by geological surveys, in order to investigate the most appropriate way to present (processed) geological data on maps of 
urbanized areas (e.g. Monroe and Hull, 1987, Forster et al. 1987, de Mulder 1986). In Spain, geotechnical maps for urban planning on a scale of 1:25,000 were made by the Instituto Geologico $y$ Minero de Espana for the cities of Huelva, Granada, Palma de Mallorca, Almeria, Malaga, Cordoba, Alcoy, and Valladolid (Instituto Geologico y Minero de Espana 1984, Cendrero et al. 1987) and for the Madrid region on scales of $1: 400,000$ to $1: 100,000$ by the Instituto Technologico GEOMINERO de Espana (Ayala Carcedo et al. 1988). The increased use of geohydrological and geotechnical models from the end of the seventies onwards made it possible to predict and to quantify the effects of human interference in the geosphere. An example of this was the prediction of the harmful effects of land subsidence resulting from land reclamation in The Netherlands (de Mulder et al. 1994). The impact of geological processes such as erosion and sedimentation on cities has been effectively and extensively described by Douglas (1988 and 1990).

The introduction of electronic data files and Geographical Information Systems (GIS) greatly facilitated the presentation of data on maps and made new applications possible. This development marked the decline of traditional, printed geological maps with 'eternal' value and the onset of custom-made maps on cheap paper from the plotter and produced on request, with a temporary value only. Thus, thematic maps became more accessible to planners, decision makers, and engineers. This development was enhanced by deleting all kinds of marginal information which would not be understood directly by the target group (the users), and by presenting these data in a more quantified manner (e.g. de Mulder 1986).

A significant development in urban geosciences occurred in the early nineties when the British Geological Survey started the LOCUS (London Computerized Underground and Surface) Project. This ambitious project aims to produce urban geological maps on various themes for land-use planning, civil engineering, and for solving geo-environmental problems (de Mulder 1996). It is based on the development of a digital database comprising more than 20,000 borehole descriptions. Map production takes place from this database by means of a GIS (Ellison et al. 1993). The introduction of increasingly powerful computers encouraged the development of more complex models which are now capable of, for example, predicting the costs for municipalities for different kinds of land-use in different types of geological setting (de Mulder 1994).

Outside Europe and North America, urban geology began to develop from the mid eighties onwards in Southeast Asia and the Pacific. This was largely a response to the stimulus provided by the activities of the Economic and Social Commission for Asia and the Pacific (ESCAP, United Nations). Six volumes of the Atlas of Urban Geology, compiled by J. Rau and published by ESCAP in Bangkok, contain the results of special urban geological studies and state-of-the-art reports from the People's Republic of China, Bangladesh, Fiji, Indonesia, Malaysia, Nepal, Pakistan, Philippines, Republic of Korea, Sri Lanka, Thailand and Vietnam. A few decades earlier, urban geological studies for the city of Calcutta (India) were carried out and published (Dastidar and Ghosh 1967) followed by a number of urban geotechnical studies scattered all over this subcontinent (Raju 1987). De Mulder (1996) mentions that in Africa no major urban geological studies or geological studies for land management, apart from Togo (Allaglo et al. 1987), Morocco (Hafdi 1987) and Zaire (Tanania 1994), are known.

In Greece, some town's microzone studies had been carried out. But these studies are not urban geologic researches. The first completed urban geologic study was the "Geological, geomorphological and geographic study of the urban areas of Trikala Prefecture - Western Thessaly" (Bathrellos 2005). After this study, which was the author's PhD Thesis, a project has started by Direction of Mapping of Greek "Institute of Geology and Mineral Exploration". This project studies the geologic settings of four Greek towns. Beyond a few other studies have been published in which are performed some problems of various Greek towns and cities (e.g. Skilodimou et al. 2002, 2003, Rozos et al. 1992, Koukis et al. 1997, Bathrellos et al. 2005, Skilodimou 2002, Bathrellos et al. 2005). 


\section{The relation among urban geomorphology and spatial planning}

Engineering geology and urban planning need to interface with geomorphology in hazardous areas. Urban geomorphological hazards can be divided into two broad groups: (1) hazards associated with city location, and (2) hazards created or accentuated by accelerated resource utilization and city metabolism (Gupta and Ahmad 1999).

It is an oversimplification to say that doing urban geomorphology is simply doing surface geology studies in cities. It is true that there are universal physical laws that operate on all land and water. However, in the urban environment man has supplanted or suppressed natural processes to such an extent that new or modified techniques are necessary to study this deformed system. For example, the concentration of population exerts increased demands on the land-water ecosystem, which is quite unlike that of other more natural geomorphic settings. Many imbalances occur in the surface water-ground water relationship with channelization and rerouting of normal streams (Coates 1976).

Urban geomorphology combines the ambient geology, landforms, and geomorphological processes with the evaluation of impacts brought to these by urbanization. The practitioners of urban geomorphology tend to concentrate on alteration, using the ambient physical environment as a baseline. A number of case studies from different parts of the world (dealing with topics such as slope instability, seismic hazards, increased flood problems, and land subsidence) have demonstrated the utility of urban geomorphology to engineers, city managers, and urban planners (Gupta and Ahmad 1999).

\section{Conclusions}

Worldwide is observed an expansion in urban areas. In Greece a proportional phenomenon is mentioned. More than $52 \%$ of the Greek population now lives in the two metropolitan municipalities of Athens and Salonica.

Urban Geology is the application of geologic knowledge to the planning and management of metropolitan areas. Its domain spans both regional geology and applied geology. Urban Geomorphology is the study of man as a physical process of change whereby he metamorphoses a more natural terrain to an anthropogene cityscape. In such a context Urban Geomorphology is the surface component of Urban Geology, which is one of the important subfields of environmental geology.

Urban Geology and Urban Geomorphology are two subfields of geology, which are sufficiently developed worldwide. In contrary in Greece they have not been opened out. Author's opinion is that these subdisciplines of Geology may be developed, aiming at better management of natural hazards. Urban geology and geomorphology need to interface with spatial and especially urban planning in hazardous areas.

\section{References}

Adams, F.D., 1898. Notes on the geology of Montreal and Vicinity, Abst. Science, 7, 51-52.

Ahnert, F., 1998. Introduction to Geomorphology, Arnold, 352pp.

Allaglo, L.K., et al., 1987. Togo, its geopotential and attempts for land-use planning - case study. In P. Arndt and G.W. Luttig (eds), Mineral Resources extraction, environmental protection and land-use planning in the industrial and developing countries. 243-270, Stuttgart, Schweizerbart.

Ami, H.M., 1885. Additional notes on the geology and paleontology of Ottawa and vicinity, Ottawa Field Naturalists Club Transactions, 6, 251-259. 
Ami, H.M., 1891. On the geology of Quebec and environs, Geological Society of America Bulletin, 2, 477-500.

Ami, H.M., 1892. Additional notes on the geology and paleontology of Ottawa and its environs, Ottawa Naturalist, 6, 73-78.

Ami, H.M., 1897. Synopsis of the geology of Montreal, British Medical Association Guide and Souvenir, 45-49.

Ami, H.M., 1900. On the geology of the principal cities in eastern Canada, Royal Society of Canada Proceedings and Transactions (2) 6, 4, 125-173.

Ayala Carcedo, F.J., et al., 1988. Atlas Geoscientifico del Medio Natural de la Comunidad de Madrid, Instituto Technologico Geominero de Espana. (in Spanish)

Baskerville, C.A., 1981. The foundation geology of New York City. In R.F. Legget (ed.), Geology under Cities. 5, 95-117 Geol. Soc. Amer. Rev. Eng. Geol.

Bathrellos, G., 2005. Geological geomorphological and geographic study of urban areas in Trikala prefecture - Western Thessaly, PHD Thesis, National and Kapodistrian University of Athens, Greece, 567pp. (in Greek)

Bathrellos, G., Skilodimou, H, and Kakalika, P., 2005. Flood risk assessment and its usage in physical and urban planning. A case study in Trikala-Kalambaka plain, Bull. of Geological Society of Greece, XXXVIII, 147-156. (in Greek)

Bathrellos, G., Skilodimou, H., Livaditis, G., and Verikiou-Papaspiridakou, E., 2005. Geomorphological and morphotectonic analysis of Malakasiotis drainage basin, Bull. of Geological Society of Greece, XXXVIII, 123-133 (in Greek).

Bruning, K., 1940. Bodenatlas von Niedersachsen, Gottingen, Germany, Wirtschaftswiss, Ges. Stud. Nieders (in German).

Cendrero, A., et al., 1987. Detailed geological hazards mapping for urban and rural planning in Viscaya (Northern Spain), Norg. Geol. Unders. sp. publ., 2, 25-41.

Coates, D., 1974. Environmental geomorphology and landscape conservation, Vol. II, Urban areas, Pennsylvania, U.S.A.,Stroudsburg, Dowden, Hutchinson \& Ross, Inc., 454pp.

Coates, D., 1976. Urban Geomorphology, Colorado, U.S.A. Geological Society of America, Sp. Paper 174, 166pp.

Cooke, R.U., 1976. Urban geomorphology, Geographical Journal, 142, 59 - 65.

Cooke, R.U., Brunsden, D., Doornkamp, J.C., and Jones, D.K.C., 1982. Urban geomorphology in drylands, Oxford, Oxford University Press, 324pp.

Dastidar, A.G., and Ghosh, P.K., 1967. Subsoil conditions of Calcutta, Journ. Inst. Eng., 48, 3, CI 2,692 .

Detwyler, T.R., and Marcus, M.G., 1972. Urbanization and environment, North Scituate, Mass., Duxbury Press, 287pp.

Douglas, I., 1988. Urban planning policies for physical constraints and environmental change. In J.M. Hooke (ed.), Geomorphology in environmental planning. New York, John Wiley \& Sons.

Douglas, I., 1990. Sediment transfer and siltation. In B.L. Turner, W.C. Clark, R.W. Kates, J.F. Richards, J.T. Mathews and E.B. Meyer (eds), The Earth as transformed by human action, 215-234, New York, Cambridge University Press. 
Drakakis-Smith, D., 1995. Third word cities: sustainable urban development, Urban Studies, 32, 459-678.

Dresser, J.A., 1897. Geological report and map of the district about Montreal, Canadian Record of Science, 7, $247-255$.

Ellison, R.A., Booth, S.J., and Strange, P.J., 1993. Geological mapping in urban areas, Episodes, $16,3,383-387$.

ESCAP, 1985. Geology for urban planning: selected papers on the Asian and Pacific region, ST/ESCAP/394 ESCAP, Bangkok, 41pp.

ESCAP, 1988a. Urban geology in Asia and the Pacific: Atlas of urban geology 2, ST/ESCAP/586 ESCAP, Bangkok, 228pp.

ESCAP, 1988b. Urban geology of coastal lowlands of China: Atlas of urban geology 3, ST/ESCAP/624 ESCAP, Bangkok, 168pp.

ESCAP, 1990. State of the environment in Asia and the Pacific 1990, ESCAP, Bangkok, 352pp.

ESCAP, 1991. Geology for land-use planning in Asia: Atlas of urban geology 4, ESCAP, Bangkok, 168pp.

ESCAP, 1992. Geology for land-use planning in tropical deltas: Atlas of urban geology 5, ST/ESCAP/983 ESCAP, Bangkok, 33pp.

ESCAP, 1993. Polders in Asia: Atlas of urban geology 6, ST/ESCAP/993 ESCAP, Bangkok, $104 \mathrm{pp}$.

Eyles, N., 1997. Environmental geology of urban areas, Newfoundland, Canada, Geological Association of Canada, Geotext 3, 590pp.

Forster, A., et al., 1987. Environmental geology maps of Bath and the surrounding area for engineering and planners. In M.G. Culshaw, et al., (eds), Planning and engineering geology, spec. Publ, 4, 221-235, Geol. Soc. Eng. Geol.

Graf, W.L., 1975. The impact of suburbanization on fluvial geomorphology, Water Resources Research, 11, 690-692.

Gregory, K.J., 1979. River channels, In K.J. Gregory and D.E. Walling (eds) Man and environmental processes. 123-143, Folkestone, Dawson \&Sons.

Gregory, K.J., and Park, C.C., 1974. Adjustment of river channel capacity downstream from a reservoir, Water Resources Research, 10, 870-883.

Gupta, A., 1984. Urban hydrology and sedimentation in the humid tropics. In J.E. Costa and J.P. Fleisher (eds), Developments and applications of geomorphology, 240-267, Berlin, Springer-Verlag.

Gupta, A., and Ahmad, R., 1999. Geomorphology and the urban tropics: building an interface between research and usage, Geomorphology, 31, 133-149.

Hafdi, A., 1987. Approach of a methodology for drawing up a habitability map, In P. Arndt and G.W. Luttig (eds), Mineral resources' extraction, environmental protection and land-use planning in industrial and developing countries. 271-278, Stuttgart, Schweitzerbart.

Hageman, B.P., 1963. A new method of representation in mapping alluvial areas, Verh. Kon. Ned. Geol. Mijnb. Gen. Geol. 21-2, Jub. Conv. 2, 211-219.

Hoyningen-Huene, P.F. von, 1931. Ubersichstkartierung im Gebiet der Messtischbšatter Kempen Krefeld, Viersen, Willich nebst Randgebieten, Briefe des Landesplannungverbandes, Duisseldorf, 21. 
Instituto Geologico y Minero de Espana, 1984. Mapa Geotechnica par ordenacion territorial urbana de Valladolid, Madrid.

Karrow, P.F., and White, O.L., 1998. Urban Geology of Canadian Cities, Newfoundland, Canada, Geological Association of Canada, Special Paper 42, 500pp.

Koukis, G., Rozos, D., and Apostolides, E., 1997. Geotechnical conditions of the geological formations at the greater area of the town of Trikala, Proc. of the $3^{\text {rd }}$ National Conference of Geotechnical Mechanics, Technical Chamber of Greece, Patras, 1, 113-119. (in Greek)

Legget, R.F., 1969. Urban Geology, Canadian Building Digest 113, Canada, National Research Council, 4pp.

Legget, R.F., 1973. Cities and Geology, New York, McGraw-Hill, 624pp.

Leopold, L.B., 1968. Hydrology for urban land planning - a guidebook on the hydrological effects of urban land use, United States Geological Survey, Circular 554.

Leveson, D., 1980. Geology and the Urban Environment, Oxford, Oxford University Press, 386pp.

Luttig, G.W., 1978. Geoscientific maps of the environment as essential tool in planning, Geologie \& Mijnbouw, 57, 4, 527-532.

McGill, J.T., 1973. Growing importance of urban geology. In R.W. Tank, (ed.), Focus in environmental geology. 378-385, New York, Oxford University Press.

Merguerian, C., and Baskerville, C.A., 1987. Geology of Manhattan Island and the Bronx, New York City. New York Geol. Soc. Amer. Cent. Field Guide - NE Section.

Monroe, S.K., and Hull, J.H., 1987. Environmental geology in Great Britain, Norg, Geol. Unders (Trondheim), spec. Publ. 2, 111.

Mulder, E.F.J. de, 1986. Applied and engineering geological mapping in The Netherlands, Proc. $5^{\text {th }}$ Int. Congr. IAEG, Buenos Aires, 5, 1755-1759.

Mulder, E.F.J. de, 1996. Urban geoscience. In G.J.H. McCall, E.F.J. de Mulder and B.R. Marker (eds), Urban geoscience. 1 - 12, Rotterdam, Balkema.

Mulder, E.F.J. de, Claessen, F.A.M., Satijin, H.M.C., Hannink, G., Bruchem, A.J. van, and Hulsbergen, J.G., 1994. Effects of reclamation of a new polder on its environment, Engineering Geology, 37, 1.

Munchenhausen, E., and Muller, E.H., 1951. Geologisch-bodenkundliche Kartierung des Stadtkreises Bottrop i. W. fur Zwecke der Stadtplanung, Geol. Jahrb., 66, 179-202.

Raju, K.C.C., 1987. Geoscientific maps in land-use planning in India. In P. Arndt and G.W. Luttig (eds), Mineral resources' extraction, environmental protection and land-use planning in industrial and developing countries. 281-298, Stuttgart, Schweitzerbart.

Rozos, D., Chatzinakos, J., and Apostolides, E., 1992. Geotechnical conditions of the geological formations at the greater industrial area of the city of Salonica, Proc of the $2^{\text {nd }}$ National Conference of Geotechnical Mechanics, Technical Chamber of Greece, Salonica, 261-268. (in Greek).

Sala, M., and Inbar, M., 1992. Some effects of urbanization in Catalan rivers, Catena, 19, 345-361.

Skilodimou, H., 2002. Geomorphological and environmental study of the coastal zone of Southwestern Attica, Phd. Thesis, National and Kapodistrian University of Athens, 267pp. (in Greek) 
Skilodimou, H., Livaditis, G., Bathrellos, G., and Verikiou-Papaspiridakou, E., 2003. Investigating the flooding events of the urban regions of Glyfada and Voula, Attica, Greece: a contribution to Urban Geomorphology, Geografiska Annaler, 85A, 2, 197-204.

Skilodimou, H., Stefouli, M., and Bathrellos, G., 2002. Spatiotemporal analysis of the coastline of Faliro Bay, Attica, Greece, Estudios Geológicos, 58 (3-4), 83-89.

Socolow, R., Andrews, C., Berkhout, F., and Thomas, V., 1994. Industrial ecology and global change, Cambridge, U.K., Cambridge University Press, 500pp.

Stremme, H., 1932. Die Bodenkartierung als wichtigste Vorarbeit der Generalplanung. In: A. Mauesmann (ed.), Die Umst im Siedlungswesen. Berlin.

Stren, R., White, R., and Whitney, J., 1992. Sustainable cities: urbanization and the environment in international perspective, Oxford, U.K., West view press, $365 \mathrm{pp}$.

Tabibzadeh, I., Rossi-Espagnet, A., and Maxwell, R., 1989. Spotlight on the cities: improving urban health in developing countries, Geneva, Switzerland, World Health Organization, $174 \mathrm{pp}$.

Tanania, K., 1994. Erosion on Kinshasa. In E.F.J. de Mulder (ed.) Cogeoenvironment. Newsletter, 5.

Turner, B.L.,II, Clark, W.C., Kates, R.W., Richards, J.F., Mathew, J. T., and Meyer, W.B., 1990. The earth as transformed by human action: Global and regional changes in biosphere over the past 300 years, Cambridge, U.K., Cambridge University Press, 454pp.

United Nations Population Fund, 1991. Populations, resources and the environment: the critical challenges, New York, 154pp.

Utgard, R.O., McKenzie, G.D., and Foley, D., 1978. Geology in the Urban Environment, Minneapolis, USA, Burgess Publishing Company, 355pp.

Viles, H.A., 1993. The environmental sensitivity of blistering of limestone walls in Oxford, England: a preliminary study. In D.S.G. Thomas and R.J. Allison (eds), Landscape sensitivity. 309-326, Chichester, John Wiley \& Sons.

Walton, M., 1982. Engineering geology of the Twin Cities area, Minnesota. In R.F. Legget (ed.), Geology under Cities. 5, 125-131 Geol. Soc. Amer. Rev. Eng. Geol.

White, O.L., 1989. Quaternary geology and urban planning in Canada. In: E.F.J. de Mulder and B.P. Hageman (eds), Applied quaternary research. 165-175, Rotterdam, Balkema.

Wolman, M.G., 1967. A cycle of sedimentation and erosion in urban river channels, Geografiska Annaler, 41(A), 385-395.

Wolman, M.G., and Schick, A.P., 1967. Effects of construction on fluvial sediment: urban and suburban areas of Maryland, Water Resources Research, 3, 451-464. 